\title{
Application of Multivariate Statistical Analysis and Water Quality Index for Quality Characterization of Parbati River, Northwestern Himalaya, India
}

\section{Gaurav Sharma}

G.B. Pant National Institute of Himalayan Environment, Himachal Regional Centre, Mohal-Kullu, Himachal Pradesh,

Renu Lata ( $\sim$ renu15_negi@yahoo.co.in )

G.B. Pant National Institute of Himalayan Environment, Himachal Regional Centre, Mohal-Kullu, Himachal Pradesh,

\section{Nandini Thakur}

G.B. Pant National Institute of Himalayan Environment, Himachal Regional Centre, Mohal-Kullu, Himachal Pradesh,

\section{Vishal Bajala}

Department of Environment Studies, Panjab University, Chandigarh

\section{J. C. Kuniyal}

G.B. Pant National Institute of Himalayan Environment, Kosi-Katarml, Almora, Uttrakhand

\section{Kireet Kumar}

G.B. Pant National Institute of Himalayan Environment, Kosi-Katarml, Almora, Uttrakhand

\section{Research Article}

Keywords: Water quality, hydrogeochemical characteristics, water quality index, principal component analysis, Piper trillinear diagram, anthropogenic activities

Posted Date: June 1st, 2021

DOI: https://doi.org/10.21203/rs.3.rs-492884/v1

License: (c) (i) This work is licensed under a Creative Commons Attribution 4.0 International License. Read Full License 


\section{Abstract}

The present study is an attempt to accomplish the understanding of the factors impacting surface water quality of Parbati river in Kullu district of Himachal Pradesh. The main objective is to assess the overall water quality, to explore its hydrogeochemical characteristics including major ion contents and other chemical parameters using Water Quality Index (WQI), statistical techniques (principal component analysis) and conventional graphical representation such as Piper trillinear diagram, Durov. Eighteen surface water sampling sites were selected to analyze physico-chemical parameters for June 2019 and September 2019. Analytical outcomes of thirty six surface water samples for both seasons are well within the permissible limits as per BIS, 2012 \& WHO 2011 for drinking and domestic purposes. Water quality characterization for the assigned use shows that maximum surface water samples falls under excellent to good water quality index and are suitable for drinking without conventional treatment. The Piper trillinear diagram classified $100 \%$ of surface water samples for both seasons' falls in the fields of $\mathrm{Ca}^{2+}-\mathrm{Mg}^{2+}-\mathrm{HCO}_{3}{ }^{-}$water type indicating temporary hardness. Abundance of ions in the water samples is in the order: anions $\mathrm{HCO}_{3}{ }^{-}>\mathrm{Cl}^{-}>\mathrm{SO}_{4}{ }^{2-}>\mathrm{NO}_{3}{ }^{-}$and cations $\mathrm{Mg}^{2+}>\mathrm{Ca}^{2+}>\mathrm{Na}^{+}>\mathrm{K}^{+}$. PCA identifies that the surface water chemistry is influenced by natural factors as well as minor anthropogenic activities in both the seasons.

\section{Introduction}

Rivers form key role in sustainable socio-economic development of a country and account for $0.006 \%$ of the freshwater resources in the world [1, 2]. The Himalayan rivers are under immense stress due to exponential population growth, industrialization, agriculture and urbanization. These anthropogenic effects combined with uncertain effects of climate change raising serious concerns on rivers both in terms of quality and quantity [3-5]. The people of Himalayan region are dependent on river water and groundwater for drinking, irrigation and other domestic purposes [6] and some towns are major tourist destinations hosting large population during peak tourist season. The discharge of untreated or partly treated sewage in river and poor waste management practices especially along the bank is deteriorating quality of river which sequentially also affecting the ground water quality in adjoining areas [7] Water portability is significantly dependent on its quality which is determined and controlled by its geochemistry in natural conditions $[8,9]$ whereas pollution in water is also dependent on seasonal variation in precipitation, surface runoff, interflow, groundwater flow from bacterial contamination and toxic elements due to their origin from anthropogenic activities [10]. Developing countries like India are more prevalent to degradation of river water quality where millions of people reside on the river banks with poor sewerage system. Therefore, it is essential to monitor water quality as it is directly related with human health and approximately $21 \%$ of communicable diseases are water related as per World Bank estimation [11, 12].

Climate changes have laid impact as there is a profound glacier retreat which has resulted in fresh water scarcity in Indian Himalayan Region (IHR) [13]. Similarly unprecedented urbanization, increased tourism, changing land use pattern, waste disposal and agricultural runoff are the main casual factors other than natural factors affecting the water quality of rivers in the Himalayan region $[14,6]$. Some parts of Kullu district in the Himalayan state of Himachal Pradesh are facing water shortage in the backdrop of climate change and anthropogenic activities $[15,16]$.

Studies on surface and groundwater monitoring with respect to WQI has been done by various [17-19] Water chemistry is constrained by various hidden factors related to natural and anthropogenic influences that are hard to comprehend and decipher significant data using simple techniques $[20,21]$. Therefore, in addition to the WQI and hydro geochemical analysis, the multivariate statistical approaches were used to understand complex information grids of water quality for efficient management and identification of effective solutions to pollution problems [22-23]. Therefore, the findings of study will provide significant information of surface water quality of river Parbati and will help to adopt quality aspect of water in a judicious and sustainable manner.

\section{Study Area}

The study area lies in Parbati valley in Kullu district of Himachal Pradesh. River Parbati is the main flowing river draining an area of $1938 \mathrm{~km}^{2}$ in the valley and the basin extends between $31^{\circ} 50^{\prime} \mathrm{N}$ and $32^{\circ} 05^{\prime} \mathrm{N}$ latitude and $77^{\circ} 05^{\prime} \mathrm{E}$ and $77^{\circ} 50^{\prime} \mathrm{E}$ longitude (Fig. 1). The Parbati river originates from Mantalai glacier at an altitude of $5200 \mathrm{~m}$ amsl and below Pin Parbati pass on the western slope of greater Himalaya and traverse down through complex topography into the river Beas at Bhunter (1096m). The river

Page 2/19 
Parbati is fast flowing, several small tributaries joins at almost every angle outlining dendritic pattern. However, the valley is tourist hotspot as it is rich in art and culture, white-capped snowy peaks, dense green forest, dazzling rivers, hot water springs and sacred places. The climate is generally cool and dry whereas annual rainfall is $1405 \mathrm{~mm}$ out of which $57 \%$ occurs in June to September [24].

\subsection{Geology and Hydrogeology}

The area under investigation comprises of Precambrian meta sedimentary now uncovered in the profoundly eroded "Kullu Rampur window" under the crystalline thrust sheets [25]. The geology of the area has been divided into three units, Manikaran quartzites, Green bed member and Bhalan member under Banjar formation which includes various high grade gneiss and schist, pegmatite, migmatite, granite and quartz veins along with carbonaceous phyllite, quartzite and limestone bands [26]. The exposed rock types around Manikaran and Kasol are white to grayish well jointed quartzites which are known as Manikaran quartzites [27]. The probable sources of high radioactivity in the area is due to intrusive tourmaline, whereas hot water emergence is through highly jointed and fractured quartzites at Manikaran and Kasol [24].

The Kullu district has two hydro geological units in the form of porous and fissured formations. Porous formation has unconsolidated sediments of terrace, valley fills and fluvial channel whereas fissured formations has semi-consolidated to consolidated sediments of sedimentary, metamorphic and igneous origin descending higher to lower altitude [14]. The porous structures of unconsolidated sediments form the potential aquifers. The occurrence of groundwater in the basin is confined to semi-confined. However, phreatic aquifers form major source of domestic and irrigation water usages in the valley.

\subsection{Drainage Pattern}

The Drainage pattern of the Parbati river exhibits tree-like dendritic pattern which is developed over sedimentary rocks (Fig. 2) [28]. Additionally, other drainage patterns are also present in the basin. Herringbone type of drainage pattern at Marhigarh Nala is one of the patterns where tributaries meet the mainstream at right angle. The trellis drainage pattern representing soft rocks like phyllitic slates and are well developed in the terrace and lower reaches of the valley [29]. In the areas of the uniformly dipping rocks, streams are running parallel to each other forming sub parallel drainage pattern. The sampling location in the study area is represented in Fig. 2.

\section{Materials And Methods}

A well approached sample technique was adopted to collect the surface water sample along the river stretch of the study area. Total of thirty six water samples, eighteen samples during pre-monsoon (June 2019) and eighteen samples during post - monsoon (September 2019) were collected from river Pārbati and its tributaries. Samples were collected in $1000 \mathrm{ml}$ best quality, sealed shut polyethylene bottles with cover lock. Physical parameters like EC, $\mathrm{pH}$, TDS were measured on the field after sample collection using portable water and soil analysis kit. Major cations $\left(\mathrm{Ca}^{2+}, \mathrm{Mg}^{2+}, \mathrm{Na}^{+}, \mathrm{K}^{+}\right)$and anions $\left(\mathrm{HCO}_{3}{ }^{-}, \mathrm{Cl}^{-}, \mathrm{SO}_{4}{ }^{2-}, \mathrm{NO}_{3}{ }^{-}\right)$were analyzed by following standard procedure given by American Public Health Association [30]. The accuracy of the chemical analysis was checked by Charge Balance Error (CBE) [31].

Charge Balance Error $(\mathrm{CBE})=\left(\sum\right.$ Cations $-\sum$ Anions $) /\left(\sum\right.$ Cations $+\sum$ Anions $) \star 100 \%$

Majority of the analyzed samples showed CBE around $\pm 10 \%$

Calcium, Magnesium, Bicarbonates, Chloride, Total alkalinity and Total hardness were determined using EDTA titrimetric method. Sodium and Potassium using flame photometric method, Nitrate and Sulphate by UV spectrophotometric method respectively. Mean value were calculated for each parameters to understand the seasonal variation as an indication of the precision of each parameter. Maps were prepared using ArcGIS 10.8 software and Piper trillinear, Durov were plotted using Grapher. The statistical software SPSS, Grapher, Aquachem and Microsoft excel were employed for the calculations and data interpretation.

\subsection{Appraisal of Water Quality Index (WQI)}


WQI is an effective mathematical tool to evaluate the suitability of water for drinking purpose [32]. It is calculated by adopting the weighted arithmetical index method [33]. In the present study physiochemical parameters namely $\mathrm{pH}, \mathrm{EC}, \mathrm{TDS}, \mathrm{TH}^{\mathrm{Ca}}{ }^{2+}, \mathrm{Mg}^{2+}, \mathrm{Cl}^{-}$, $\mathrm{SO}_{4}{ }^{2-}, \mathrm{NO}_{3}{ }^{-}$were considered for computing WQI for river Parbati. Tiwari and Mishra (1985) developed an equation to calculate WQI, the calculation involves following steps (Eq. 2-5):

$W Q I=\sum q_{n} W_{n} / W_{n} \quad$ Eq. 2

Where, $W_{n}=$ unit weight of $n^{\text {th }}$ parameters, is calculated by the equation

$$
W_{n}=\mathrm{K} / \mathrm{S}_{\mathrm{n}} \quad \text { Eq. } 3
$$

and $\mathrm{K}$, is the proportionality constant obtained from,

$\mathrm{K}=\left[1 /\left(\sum_{\mathrm{i}=0}^{\mathrm{n}} 1 / S_{i}\right)\right] \quad$ Eq. 4

Where, Sn and Si are the BIS standard values of the water quality parameter

$\mathrm{q}_{\mathrm{ni}}=100 \times V a-V i / V s-V i \quad$ Eq. 5

$\mathrm{q}_{\mathrm{ni}}$ is the quality rating of the $\mathrm{i}^{\text {th }}$ parameter for a total of $\mathrm{n}$ water quality parameters

Where, $\mathrm{Va}=$ value of the water quality parameter obtained from laboratory analysis, $\mathrm{Vi}=$ ideal value (for $\mathrm{pH}=7$ and 0 for other parameters) and Vs = BIS standard value of water quality parameters.

\subsection{Evaluation of hydrogeochemical facies of surface water}

To comprehend the hydro geochemical attributes of surface water, different plots were utilized specifically, Piper, Durov and Gibbs plot [34-36]. These plots represent the graphical relationship characterizing different geochemical marks in surface water samples. The grapher 12.0 was used to prepare the Piper diagram and Durov, while Gibbs plot was prepared by aquachem software.

\subsection{Multivariate statistical analysis}

Multivariate Statistical techniques have been used to organize and simplify datasets and characterize freshwater, marine water and sediment quality [37-39]. In recent years, water quality assessment has been widely done using multivariate statistical techniques $[40,41]$

Correlation analysis is a technique which determines the correlation coefficient between variables. The relationship between two variables can be measured by the strength and significance of the variables. The strength is indicated by the correlation (r), whereas the significance is expressed in probability levels ( $p$ values). Larger the correlation coefficient, stronger the relationship, whereas smaller the $\mathrm{p}$ level, more significant the relationship.

Statistical extraction of linear relationship from a given set of variables is performed by applying Principal Component Analysis (PCA) technique [22]. PCA allows to gain insight into the data without significant loss of information in the process [42, 43]. Principal components generated during the analysis are arranged in such a manner that they correspond to decreasing contribution of variance, i.e., principal component 1 (PC1) explains the highest amount of variance in the original data $[44,45]$ classified the factor loadings as "strong", "moderate" and "weak", corresponding to absolute loading values of $0.75,0.75-0.50$ and $0.50-0.30$, respectively. However, loading reflects the relative importance of a variable within the component and does not reflect the importance of the component itself [46].

\section{Results And Discussion}

Statistical summary of river water samples analyzed for various physio-chemical parameters is given in Table 2 with permissible limits prescribed by BIS and WHO $[47,48]$. Mean value for all physio-chemical parameters, except $\mathrm{Ca}^{2+}, \mathrm{Na}^{+}, \mathrm{K}^{+}$and $\mathrm{Cl}^{-}$, were showing higher values during the pre-monsoon period than post-monsoon.; EC accounted for $100 \%$ within desirable limit with 
mean values 93.44 and $81.05 \mu \mathrm{S} / \mathrm{cm}$ during the period of investigation. TDS values were well within desirable limit in both seasons with mean values 58.8 and $51.06 \mathrm{mg} / \mathrm{l}$. The average values of total hardness are $95.36 \mathrm{mg} / \mathrm{l}$ in pre-monsoon and 83.44 $\mathrm{mg} / \mathrm{l}$ in post-monsoon, respectively. Classification of river water based on total hardness [49] and total dissolved solids [50] are shown in Table 1. Further during the lab analysis higher soluble concentration of $\mathrm{Ca}^{2+}, \mathrm{Mg}^{2+}$ and $\mathrm{HC}^{\prime} \mathrm{O}_{3}{ }^{-}$ions was found which may contribute to increased hardness of river water samples. Magnesium accounted for $12.62 \mathrm{mg} / \mathrm{l}$ in pre-monsoon and 8.85 $\mathrm{mg} / \mathrm{l}$ for post-monsoon representing samples within desirable limits as the calcium starts precipitating after super saturation has been attained the dissolved concentration of magnesium exceeds that of calcium. Weathering of sandstone and dolomite, in the study area, accounts for higher concentration of $\mathrm{Mg}^{2+}$ found during the analysis [51]. Mean value of $\mathrm{HCO}_{3}{ }^{-}$was more significant during pre-monsoon due to dissolution of carbonate rocks, weathering of feldspar by carbonic acids and oxidation of $\mathrm{NO}_{3}{ }^{-}$and $\mathrm{SO}_{4}{ }^{2-}$ with organic matter as compared to post-monsoon [52]. The parameters like $\mathrm{Na}^{+}, \mathrm{K}^{+}, \mathrm{Cl}^{-}, \mathrm{NO}_{3}{ }^{-}, \mathrm{SO}_{4}{ }^{2-}$ and $\mathrm{Mg}^{2+}$ were all within the desirable range. During the pre-monsoon season the ionic dominance pattern in the water is governed by cationic species in the order of $\mathrm{Mg}^{2+}>\mathrm{Ca}^{2+}>\mathrm{Na}^{+}$and $\mathrm{K}^{+}$. However, during the post-monsoon season, such dominance of cations is exceeded by that of anionic species in the order of $\mathrm{HCO}_{3}{ }^{-}>\mathrm{SO}_{4}{ }^{2-}>\mathrm{NO}_{3}{ }^{-}>\mathrm{Cl}^{-}$.

Table 1

Classification of surface water based on total hardness and total dissolved solids

\begin{tabular}{|c|c|c|c|c|c|c|c|}
\hline $\begin{array}{l}\mathrm{TH} \text { (as } \\
\mathrm{CaCO}_{3} \\
\mathrm{mg} / \mathrm{l})\end{array}$ & $\begin{array}{l}\text { Water } \\
\text { Classification }\end{array}$ & $\begin{array}{l}\text { Pre- } \\
\text { monsoon } \\
\text { samples } \\
(\%)\end{array}$ & $\begin{array}{l}\begin{array}{l}\text { Post- } \\
\text { monsoon }\end{array} \\
\text { samples } \\
(\%)\end{array}$ & $\begin{array}{l}\text { TDS } \\
(\mathrm{mg} / \mathrm{l})\end{array}$ & Water category & $\begin{array}{l}\text { Pre- } \\
\text { monsoon } \\
\text { samples } \\
(\%)\end{array}$ & $\begin{array}{l}\text { Post-monsoon } \\
\text { samples (\%) }\end{array}$ \\
\hline$<75$ & Soft & $12 \%$ & $28 \%$ & $<500$ & $\begin{array}{l}\text { desirable for domestic } \\
\text { purposes }\end{array}$ & $100 \%$ & $100 \%$ \\
\hline $75-150$ & $\begin{array}{l}\text { Moderately } \\
\text { Hard }\end{array}$ & $82 \%$ & $72 \%$ & $\begin{array}{l}500- \\
1000\end{array}$ & $\begin{array}{l}\text { Permissible for domestic } \\
\text { purposes }\end{array}$ & - & - \\
\hline $150-300$ & Hard & - & - & $\begin{array}{l}1000- \\
3000\end{array}$ & Useful for irrigation & - & - \\
\hline$>300$ & Very Hard & - & - & $>3000$ & $\begin{array}{l}\text { Not fit for both domestic } \\
\& \text { agricultural purposes }\end{array}$ & - & - \\
\hline
\end{tabular}


Table 2

Statistical summary of physicochemical parameters of surface water of the study area

\begin{tabular}{|c|c|c|c|c|c|c|c|c|c|}
\hline \multirow[t]{3}{*}{ Parameters } & \multicolumn{2}{|c|}{$\begin{array}{l}\text { Prescribed limit IS: } \\
150500,2012\end{array}$} & \multicolumn{3}{|c|}{ Pre-monsoon } & \multicolumn{3}{|c|}{ Post-monsoon } & \multirow[t]{3}{*}{$\begin{array}{l}\text { Undesirable effect produced } \\
\text { beyond the MPL }\end{array}$} \\
\hline & \multirow[t]{2}{*}{ PL } & \multirow[t]{2}{*}{ DL } & \multicolumn{2}{|l|}{ Range } & \multirow[t]{2}{*}{ Mean } & \multicolumn{2}{|c|}{ Range } & \multirow[t]{2}{*}{ Mean } & \\
\hline & & & Min. & Max. & & Min. & Max. & & \\
\hline $\mathrm{pH}$ & - & $\begin{array}{l}6.5- \\
8.5\end{array}$ & 6.7 & 8.6 & 7.66 & 6.48 & 7.32 & 6.84 & Taste effects, mucus membrane \\
\hline EC & $\begin{array}{l}2000 \\
\mu S / \mathrm{cm}\end{array}$ & $\begin{array}{l}750 \\
\mu S / c m\end{array}$ & 78 & 108 & 93.44 & 72 & 96 & 81.05 & $\begin{array}{l}\text { High concentration laxative } \\
\text { effect on human }\end{array}$ \\
\hline TDS & $\begin{array}{l}2000 \\
\mathrm{mg} / \mathrm{l}\end{array}$ & $\begin{array}{l}500 \\
\mathrm{mg} / \mathrm{l}\end{array}$ & 49.14 & 68.04 & 58.8 & 45 & 60.48 & 51.06 & Gastrointestinal irritation \\
\hline $\mathrm{TH}$ & $\begin{array}{l}600 \\
\mathrm{mg} / \mathrm{l}\end{array}$ & $\begin{array}{l}300 \\
\mathrm{mg} / \mathrm{l}\end{array}$ & 60 & 124 & 95.36 & 64 & 116 & 83.44 & $\begin{array}{l}\text { Calcification at arteries, } \\
\text { gastrointestinal irritation }\end{array}$ \\
\hline \multicolumn{10}{|l|}{$\begin{array}{l}\text { Major } \\
\text { Cations }\end{array}$} \\
\hline $\mathrm{Ca}^{2+}$ & $\begin{array}{l}200 \\
\mathrm{mg} / \mathrm{l}\end{array}$ & $\begin{array}{l}75 \\
\mathrm{mg} / \mathrm{l}\end{array}$ & 15.13 & 20.18 & 17.38 & 1.13 & 26.91 & 18.83 & $\begin{array}{l}\text { May cause kidney and bladder } \\
\text { problems }\end{array}$ \\
\hline $\mathrm{Mg}^{2+}$ & $\begin{array}{l}100 \\
\mathrm{mg} / \mathrm{l}\end{array}$ & $\begin{array}{l}30 \\
\mathrm{mg} / \mathrm{l}\end{array}$ & 2.38 & 19.97 & 12.62 & 4.8 & 15.94 & 8.85 & Laxative effect \\
\hline $\mathrm{Na}^{+}$ & $\begin{array}{l}200 \\
\mathrm{mg} / \mathrm{l}\end{array}$ & & 1.8 & 2.9 & 2.6 & 2.4 & 4.2 & 3.4 & High blood pressure \\
\hline $\mathrm{K}^{+}$ & $12 \mathrm{mg} / \mathrm{l}$ & & 3.6 & 4.2 & 3.8 & 3.2 & 4.8 & 3.85 & $\begin{array}{l}\text { bitter taste, laxative effects on } \\
\text { human digestive and nervous } \\
\text { system }\end{array}$ \\
\hline \multicolumn{10}{|c|}{ Major Anions } \\
\hline $\mathrm{HCO}_{3}{ }^{-}$ & $\begin{array}{l}600 \\
\mathrm{mg} / \mathrm{l}\end{array}$ & $\begin{array}{l}200 \\
\mathrm{mg} / \mathrm{l}\end{array}$ & 91.5 & 183 & 122 & 91.5 & 152.5 & 108.44 & $\begin{array}{l}\text { Combined with } \mathrm{Ca}^{2+} \text { and } \mathrm{Mg}^{2+} \\
\text { forms carbonate hardness }\end{array}$ \\
\hline $\mathrm{Cl}^{-}$ & $\begin{array}{l}1000 \\
\mathrm{mg} / \mathrm{l}\end{array}$ & $\begin{array}{l}250 \\
\mathrm{mg} / \mathrm{l}\end{array}$ & 2.55 & 4.11 & 3.69 & 3.26 & 4.6 & 4.03 & $\begin{array}{l}\text { Injurious to people with heart } \\
\text { and kidney }\end{array}$ \\
\hline $\mathrm{NO}_{3}{ }^{-}$ & - & $\begin{array}{l}45 \\
\mathrm{mg} / \mathrm{l}\end{array}$ & 0.8 & 1.8 & 1.27 & 0.984 & 2.1 & 1.52 & Methemoglobinemia in infants \\
\hline $\mathrm{SO}_{4}^{-}$ & $\begin{array}{l}400 \\
\mathrm{mg} / \mathrm{l}\end{array}$ & $\begin{array}{l}200 \\
\mathrm{mg} / \mathrm{l}\end{array}$ & 1.84 & 3.4 & 2.58 & 2.36 & 3.6 & 3.02 & $\begin{array}{l}\text { Gastrointestinal irritation along } \\
\text { with } \mathrm{Mg} \text { or } \mathrm{Na} \text {, can have a } \\
\text { cathartic effect on users }\end{array}$ \\
\hline
\end{tabular}

\subsection{Hydrogeochemical evaluation}

Hydrogeochemical facies layouts in the form of graphical representation aiming to provide the analogies, dissimilarities and interpretation of evolutionary trends and different type of water in a particular area. For studying the effects of mixing water within the different lithological frameworks and for understanding various geochemical processes the value of graphical representation techniques is of immense importance. Many researchers such as Piper, Chadha, Collins and Black have contributed to the concept of graphical representation of geochemical analysis of water [ 53-54, 34].

\subsection{Piper trillinear diagram}

Piper diagrams are widely applied to graphically study the sources of dissolved constituents in water samples [34]. The ionic concentration was plotted in piper diagram to characterize the hydrochemistry of surface water in the study area (Fig. 3a \& b). Piper diagram shows that all the samples are in $\mathrm{Ca}^{2+}-\mathrm{Mg}^{2+}-\mathrm{HCO}_{3}{ }^{-}$facies belongs to temporary hardness and alkaline earth elements $\left(\mathrm{Ca}^{2+}+\mathrm{Mg}^{2+}\right)$ exceeding the alkali elements $\left(\mathrm{Na}^{+}+\mathrm{K}^{+}\right)$where $\mathrm{Ca}^{2+}$ and $\mathrm{Mg}^{2+}$ are leading cations in the study area 
shown in Table 3. Further, it was found that the concentration of weak acids $\left(\mathrm{CO}_{3}{ }^{2-}+\mathrm{HCO}_{3}{ }^{-}\right)$, during both the seasons, is higher than the strong acids $\left(\mathrm{SO}_{4}{ }^{2-}\right.$ and $\left.\mathrm{Cl}^{-}\right)$. This further indicates the presence of $\mathrm{HCO}_{3}{ }^{-}$as principal anion in the surface water. The Cation triangle shows that $16 \%$ samples are $\mathrm{Ca}^{2+}$ type, $56 \%$ in $\mathrm{Mg}^{2+}$ and remaining $28 \%$ falls in no dominant cation zone for pre monsoon (Fig. 3a), whereas in post monsoon $44 \%$ is dominating in $\mathrm{Mg}^{2+}$ zone, $33 \%$ in no dominating zone and $23 \%$ in $\mathrm{Ca}^{2+}$ type (Fig. 3b). The anion triangle exhibits that $\mathrm{HCO}_{3}{ }^{-}(100 \%)$ is the dominant ion during pre-monsoon and post-monsoon (Table 3). Consequently, concentration of ions such as $\mathrm{Na}^{+}, \mathrm{K}^{+}$and $\mathrm{Cl}^{-}, \mathrm{SO}_{4}{ }^{2-}$ is very low and thus insignificant in both the seasons. As all the samples fall within the field of $\mathrm{Ca}^{2+}-\mathrm{Mg}^{2+}-\mathrm{HCO}_{3}{ }^{-}$water type, we can infer that the surface water chemistry is controlled by leaching process of dolomites, limestones and gypsum.

Table 3

Surface water samples characterization based on Piper diagram

\section{Surface water samples characterization based on Piper diagram}

Samples in the different category

$\begin{array}{lll}\text { Class Surface water types corresponding subdivision of facies } & \begin{array}{l}\text { Pre- } \\ \text { monsoon }\end{array} & \text { Post-monsoon }\end{array}$

\begin{tabular}{|c|c|c|c|c|c|}
\hline & & $\begin{array}{l}\text { No. of } \\
\text { samples }\end{array}$ & Percentage & $\begin{array}{l}\text { No. of } \\
\text { samples }\end{array}$ & Percentage \\
\hline I & $\mathrm{Ca}^{2+}-\mathrm{Mg}^{2+}-\mathrm{Cl}^{-}-\mathrm{SO}_{4}{ }^{2-}$ & - & - & - & - \\
\hline II & $\mathrm{Na}^{+}-\mathrm{K}^{+}-\mathrm{Cl}^{-}-\mathrm{SO}_{4}{ }^{2-}$ & - & - & - & - \\
\hline III & $\mathrm{Na}^{+}-\mathrm{K}^{+}-\mathrm{HCO}_{3}^{-}$ & - & - & - & - \\
\hline IV & $\mathrm{Ca}^{2+}-\mathrm{Mg}^{2+}-\mathrm{HCO}_{3}^{-}$ & 18 & 100 & 18 & 100 \\
\hline 1 & $\begin{array}{l}\mathrm{HCO}^{-}-\mathrm{CO}_{3}{ }^{2-} \text { - and } \mathrm{Ca}^{2+}-\mathrm{Mg}^{2+} \text { (temporary Hardness); } \\
\text { magnesium bicarbonate type (carbonate hardness exceeds } \\
50 \%)\end{array}$ & 18 & 100 & 18 & 100 \\
\hline 2 & $\begin{array}{l}\mathrm{Cl}--\mathrm{SO} 42-\text { and } \mathrm{Na}+-\mathrm{K}+(\text { Saline); Sodium chloride type (non } \\
\text { carbonate alkali exceeds } 50 \% \text { ) }\end{array}$ & - & - & - & - \\
\hline 3 & $\begin{array}{l}\text { Mixing zone ( } \mathrm{Ca} 2+-\mathrm{Na}+-\mathrm{HCO}-\text {-); base ion exchange } \\
\text { processes }\end{array}$ & - & - & - & - \\
\hline 4 & $\begin{array}{l}\text { Mixing zone ( } \mathrm{Ca} 2+-\mathrm{Mg} 2+-\mathrm{Cl}-\text { );reverse ion exchange } \\
\text { processes }\end{array}$ & - & - & - & - \\
\hline 5 & $\begin{array}{l}\mathrm{Cl}-\text { - SO42- and } \mathrm{Ca} 2+-\mathrm{Mg} 2+\text { (Permanent hardness); Calcium } \\
\text { chloride type (non carbonate hardness exceeds } 50 \% \text { ) }\end{array}$ & - & - & - & - \\
\hline 6 & $\begin{array}{l}\mathrm{HCO} 3-\mathrm{CO} 32-\text { and } \mathrm{Na}+-\mathrm{K}+\text { (alkali carbonate); Sodium } \\
\text { bicarbonate type (carbonate alkali exceeds } 50 \% \text { ) }\end{array}$ & - & - & - & - \\
\hline
\end{tabular}

\subsection{Durov plot}

Durov plot is a significant graphical structure that gives better data on the hydrochemical portrayal and possible geochemical processes (mixing, cation exchange, reverse ion exchange dissolution) influencing the water quality of the area. This diagram is a composite plot consisting of two ternary diagrams where the milli equivalents percentages of the cations of interest were plotted against that of anions of interest; sides form a central rectangular, binary plot of total cation vs. total anion concentrations [56]. This diagram is very useful in indicating the samples with similar chemical composition as well as determines a useful relationship among different water samples [57]. The Durov plot of the water samples indicates that there are mainly two geochemical processes that could affect the genesis of water in the study area (Fig. 4a \& b). According to the classification of [57], $88 \%$ samples in Pre-monsoon and $86 \%$ in Post-monsoon belong to $\mathrm{HCO}_{3}{ }^{-}$and $\mathrm{Mg}^{2+}$ dominant cation, this water type indicates probable mixing, uncommon dissolution influences and reverse ion exchange process (Fig. 4a) whereas 12\% samples in pre- 
monsoon and $14 \%$ samples in post-monsoon falls where $\mathrm{HCO}_{3}{ }^{-}$and $\mathrm{Ca}^{2+}$ dominant type of water, indicating the partial ion exchange processes (Fig. 4b). None of the data points lie in the lower-right side of the boomerang, where water composition is dominated by atmospheric precipitation process.

\subsection{Gibbs Plot}

Hydrochemical processes such as precipitation, rock water interaction and evaporation are well interpreted through gibbs plot [34]. Gibbs demonstrated that if total dissolved solid is plotted against $\mathrm{Na}+\mathrm{K} /(\mathrm{Na}+\mathrm{Ca}+\mathrm{K})$, it would provide information on the mechanism controlling chemistry of water. Collectively, the chemistry of water is influenced by the following three main factors: (1) evaporation dominance; (2) precipitation dominance and (3) rock dominance. Figure 5 exhibits that all the surface water samples for pre-monsoon and post-monsoon fall in the precipitation dominance zone which indicates that water is mainly controlled by rock dominance however geochemical process such as precipitation -dissolution; oxidation -reduction and ion exchange are the main governing factors of water chemistry.

The studies in other parts of Himalayan regions confirmed rock dominance as main factor for controlling ionic composition in water bodies [58, 59 and 6]. In the study area due to long time rock water interaction, percolations and flow through the rocky lithology has resulted in high solute concentration which is significantly controlling the water quality of the area. However, during post monsoon there is minor influence of precipitation dominance and melting of ice in the region. This reflects that water chemistry is mainly controlled by interaction of rock formation with precipitation for both seasons in Parbati river.

\subsection{Water Quality Index}

The cumulative effect of various physio-chemical parameters governing the overall water quality is holistically represented in Water Quality Index (WQI). Thus, WQI comprehensively reports the overall quality of river water samples analyzed during the study period. For calculating WQI a weighted arithmetical index method is applied using following physio-chemical parameters- $\mathrm{pH}$, electrical conductivity $\left(\mathrm{EC}\right.$ in $\mu \mathrm{S} / \mathrm{cm}$ ), total dissolved solid (TDS in $\mathrm{mg} / \mathrm{L}$ ), total hardness (in $\mathrm{mg} \mathrm{CaCO}_{3}$ ), total alkalinity $\left(\right.$ as $\mathrm{CaCO}_{3}$ ) (mg/L), $\mathrm{Ca}^{2+}(\mathrm{mg} / \mathrm{L}), \mathrm{Mg}^{2+}(\mathrm{mg} / \mathrm{L}), \mathrm{Cl}^{-}(\mathrm{mg} / \mathrm{L}), \mathrm{SO}_{4}{ }^{2-}(\mathrm{mg} / \mathrm{L})$ and $\mathrm{NO}_{3}{ }^{-}(\mathrm{mg} / \mathrm{L})$. To calculate the WQI the WHO 2011 standards were used. The weighted arithmetic index method [60] has been used for the calculation. WQI reveals variation in the water quality status related to suitability for human consumption.

A perusal of Table 4 reveals that $22 \%$ water samples in pre-monsoon and $50 \%$ water samples in post monsoon season respectively fall in excellent class whereas $73 \%$ water samples in pre monsoon and $50 \%$ water samples in post-monsoon falling in good class. Water quality of the river water samples has WQI $=<50$ which represents the excellent to good water quality of analyzed river water samples (Table 4) and Table 5. Shows the WQI for individual samples.

Table 4

WQI Categorization

\begin{tabular}{|lllllll|}
\hline Sr.No. & WQI & Status & Pre-monsoon & Post-monsoon & \\
& & & Samples & Percentage (\%) & Samples & Percentage (\%) \\
& & & (in numbers) & & (in numbers) & \\
\hline 1 & $0-25$ & Excellent & 4 & 22 & 9 & 50 \\
\hline 2 & $26-50$ & Good & 13 & 73 & 9 & 50 \\
\hline 3 & $51-75$ & Poor & 1 & 5 & - & - \\
\hline 4 & $76-100$ & Very poor & - & - & - & - \\
\hline 5 & $>100$ & Unfit & - & - & - & - \\
\hline
\end{tabular}


Table 5

WQI Calculation for individual water sampling locations

\begin{tabular}{|c|c|c|c|c|c|}
\hline & Pre-Monsoon & & & Post-Mons & \\
\hline S.No. & Locations & WQI Value & WQI Class & WQI Value & WQI Class \\
\hline 1 & Nhyarathach & 32.19 & Good & 22.48 & Excellent \\
\hline 2 & Rudranag & 21.44 & Excellent & 19.48 & Excellent \\
\hline 3 & Parvati river Guwacha & 20.30 & Excellent & 21.36 & Excellent \\
\hline 4 & Tosh nala & 24.73 & Excellent & 22.84 & Excellent \\
\hline 5 & Barshaini Tail pt & 26.62 & Good & 22.95 & Excellent \\
\hline 6 & Manikaran bridge & 33.76 & Good & 26.45 & Good \\
\hline 7 & Manikaran NHPC & 35.86 & Good & 23.65 & Excellent \\
\hline 8 & Grahan nalla & 24.51 & Excellent & 22.29 & Excellent \\
\hline 9 & Kasol & 39.66 & Good & 26.31 & Good \\
\hline 10 & Katagla & 37.55 & Good & 28.43 & Good \\
\hline 11 & Sumaropa & 34.21 & Good & 26.45 & Good \\
\hline 12 & Malana Jari & 36.64 & Good & 24.72 & Excellent \\
\hline 13 & Shat nalla & 37.00 & Good & 24.65 & Excellent \\
\hline 14 & Shat Parvati confluence & 36.09 & Good & 28.45 & Good \\
\hline 15 & Charod & 35.71 & Good & 32.34 & Good \\
\hline 16 & Jiyah & 49.08 & Good & 36.40 & Good \\
\hline 17 & Hathithan & 48.53 & Good & 32.45 & Good \\
\hline 18 & Bhunter(Confluence) & 53.42 & Poor & 38.45 & Good \\
\hline 19 & Overall Quality & 34.85 & Good & 26.67 & Good \\
\hline
\end{tabular}

\subsection{Correlation matrix}

The Pearson's correlation coefficient ( $r$ ) was prepared to assess correlation among pH, EC, TDS, Hardness and various chemical constituents variables for surface water in pre-monsoon (June 2019) and post-monsoon (September 2019). Several parameters are found to be strong positive $(r, 0.8)$ and positive correlated $(r>0.5-0.79)$. During pre-monsoon a strong positive correlation value exist between EC-TDS and $\mathrm{TH}-\mathrm{Mg}^{2+}-\mathrm{HCO}_{3}{ }^{-}$whereas positive correlation observed in $\mathrm{TH}-\mathrm{Ca}^{2+}, \mathrm{Mg}^{2+}-\mathrm{HCO}_{3}{ }^{-}, \mathrm{Cl}^{-}-\mathrm{HCO}_{3}{ }^{-}$and $\mathrm{Na}^{2+}-\mathrm{HCO}_{3}{ }^{-}$indicating that these chemical parameters are from similar sources and can be attributed to geogenic process, while water traveling over sedimentary and metamorphic rocks which dissolve calcium, magnesium, chlorides and carbonates in it [61] (Table 6a). The positive correlation indicated influence of one parameter over other. However during post-monsoon showed strong positive correlation among EC-TDS, $\mathrm{TH}-\mathrm{Mg}^{2+}-\mathrm{Ca}^{2+}-\mathrm{HCO}_{3}{ }^{-}$indicating to the dissolution of limestone with the incoming water sources whereas positive correlation between $\mathrm{TH}^{-} \mathrm{K}^{+}-\mathrm{SO}_{4}{ }^{2-}$ have distinctive resources (Table 6a). 
Table 6

a: Matrix of correlation for water variables during pre-monsoon

\begin{tabular}{|c|c|c|c|c|c|c|c|c|c|c|c|c|}
\hline & $p H$ & $E C$ & TDS & $T H$ & $\mathrm{Mg}^{2+}$ & $\mathrm{Ca}^{2+}$ & $K+$ & $\mathrm{Na}^{+}$ & $\mathrm{Cl}^{-}$ & $\mathrm{HCO}^{-}$ & $\mathrm{SO}_{4}{ }^{2-}$ & $\mathrm{NO}^{-}$ \\
\hline$p H$ & 1.00 & & & & & & & & & & & \\
\hline$E C$ & -0.58 & 1.00 & & & & & & & & & & \\
\hline$T D S$ & -0.58 & 1.00 & 1.00 & & & & & & & & & \\
\hline$T H$ & 0.03 & 0.20 & 0.20 & 1.00 & & & & & & & & \\
\hline$M g^{2+}$ & 0.07 & 0.19 & 0.19 & 0.98 & 1.00 & & & & & & & \\
\hline $\mathrm{Ca}^{2+}$ & 0.03 & 0.04 & 0.04 & 0.54 & -0.14 & 1.00 & & & & & & \\
\hline$K+$ & 0.18 & 0.19 & 0.19 & -0.18 & -0.23 & 0.31 & 1.00 & & & & & \\
\hline $\mathrm{Na}^{+}$ & 0.25 & -0.22 & -0.22 & 0.34 & 0.32 & 0.01 & 0.14 & 1.00 & & & & \\
\hline $\mathrm{Cl}^{-}$ & 0.25 & 0.12 & 0.12 & 0.34 & 0.32 & 0.01 & 0.14 & 1.00 & 1.00 & & & \\
\hline $\mathrm{HCO}^{-}$ & -0.07 & -0.05 & -0.05 & 0.79 & 0.77 & -0.07 & 0.08 & 0.61 & 0.61 & 1.00 & & \\
\hline $\mathrm{SO}_{4}^{2-}$ & 0.28 & 0.15 & 0.15 & 0.20 & -0.13 & -0.15 & -0.47 & -0.26 & -0.26 & -0.15 & 1.00 & \\
\hline $\mathrm{NO}^{-}$ & 0.09 & -0.13 & -0.13 & -0.14 & -0.14 & 0.06 & 0.03 & -0.27 & -0.27 & -0.19 & -0.14 & 1.00 \\
\hline
\end{tabular}

Table 6

b: Matrix of correlation for water variables during post-monsoon

\begin{tabular}{|c|c|c|c|c|c|c|c|c|c|c|c|c|}
\hline & $p H$ & $E C$ & TDS & $T H$ & $\mathrm{Mg}^{2+}$ & $\mathrm{Ca}^{2+}$ & $K+$ & $\mathrm{Na}^{+}$ & $\mathrm{Cr}^{-}$ & $\mathrm{HCO}^{-}$ & $\mathrm{SO}_{4}{ }^{2-}$ & $\mathrm{NO}^{-}$ \\
\hline$p H$ & 1.00 & & & & & & & & & & & \\
\hline$E C$ & 0.11 & 1.00 & & & & & & & & & & \\
\hline$T D S$ & 0.11 & 1.00 & 1.00 & & & & & & & & & \\
\hline$T H$ & 0.14 & 0.38 & 0.38 & 1.00 & & & & & & & & \\
\hline$M g^{2+}$ & 0.05 & 0.08 & 0.08 & 0.94 & 1.00 & & & & & & & \\
\hline $\mathrm{Ca}^{2+}$ & 0.08 & 0.61 & 0.61 & 0.82 & -0.15 & 1.00 & & & & & & \\
\hline$K+$ & 0.24 & 0.20 & 0.20 & 0.62 & 0.49 & 0.33 & 1.00 & & & & & \\
\hline $\mathrm{Na}^{+}$ & 0.37 & 0.24 & 0.24 & 0.20 & 0.20 & 0.03 & -0.11 & 1.00 & & & & \\
\hline $\mathrm{Cl}^{-}$ & 0.01 & 0.58 & 0.58 & 0.32 & 0.15 & 0.36 & 0.17 & 0.32 & 1.00 & & & \\
\hline $\mathrm{HCO}^{-}$ & 0.06 & 0.15 & 0.15 & 0.84 & 0.73 & 0.18 & 0.51 & -0.17 & 0.17 & 1.00 & & \\
\hline $\mathrm{SO}_{4}^{2-}$ & 0.39 & 0.29 & 0.29 & 0.60 & 0.36 & 0.32 & 0.15 & 0.02 & 0.42 & 0.28 & 1.00 & \\
\hline $\mathrm{NO}^{-}$ & -0.32 & 0.39 & 0.39 & 0.16 & 0.12 & 0.10 & 0.24 & -0.10 & 0.02 & 0.13 & -0.03 & 1.00 \\
\hline
\end{tabular}

\subsection{Principal Component Analysis (PCA)}

To distinguish the latent factors influencing the hydrochemistry, PCA was applied on analyzed parameters of surface water samples. Principal components (PCs) taken for interpretation having eigen values $>0.75$ and additionally second level of 
interpretation are considered statistically significant $[62,23]$. Table 7 shows the component loading factors, cumulative percentage and percentages of variance and communality explained by each principal component. Standardized datasets were employed for performing PCA and in varimax rotated component matrix only four PCs, whose eigen value is greater than 1, explained $81.17 \%$ and $77.64 \%$ of the total variance for pre-monsoon and post-monsoon period, respectively. A scree plot representing all the PCs which were extracted during PCA is shown in Fig. 6 (a \& b).

During the pre-monsoon period, PC1 explains approximately 1/3rd i.e., 30.35\% of the total variance and has strong positive correlation value with Total Hardness, $\mathrm{Mg}^{2+}$ and $\mathrm{HCO}_{3}{ }^{-}$and a moderately strong positive correlation with $\mathrm{Na}^{+}$and $\mathrm{Cl}^{-}$which reflects the role of lithogenic factors in influencing the water chemistry [63]. High-positive loading of $\mathrm{Mg}^{2+}$ and $\mathrm{HCO}_{3}{ }^{-}$with $\mathrm{TH}$ shows temporary hardness in the water. Strong correlation of $\mathrm{HCO}_{3}{ }^{-}$ions with alkali and alkaline earth metals indicated the natural weathering sources $[63,64]$. PC2 $\left(25.30 \%\right.$ of total variance) has moderate positive correlation with $\mathrm{Na}^{+}$and $\mathrm{Cl}^{-}$and strong negative correlation with EC and TDS. Different hydrogeochemical processes that contribute to enrich more mineralized water is due to the combinations of $\mathrm{Na}^{+}, \mathrm{Cl}^{-}, \mathrm{HCO}_{3}{ }^{-}, \mathrm{SO}_{4}{ }^{-}$ions. $\mathrm{PC} 3$ was strongly positive weighted on $\mathrm{Ca}^{2+}$ and $\mathrm{K}^{+}$and moderate positive score on $\mathrm{Na}^{+}$accounts for $16.37 \%$. PC4 explains $9.15 \%$ of the total variance observed and has strong positive correlation with $\mathrm{NO}_{3}{ }^{-}$which points towards the role of agricultural runoff (NPK) along with the seepage of wastewater into the surface water bodies.

For post-monsoon period, again PC1 explains 1/3rd i.e., 34.32\% of the total variance and has a strong positive loading with EC, TDS and TH and a moderately positive correlation with $\mathrm{Ca}^{2+}, \mathrm{K}^{+}, \mathrm{HCO}_{3}{ }^{-}$and $\mathrm{Cl}^{-}$. The high positive correlation of $\mathrm{Mg}^{2+}$ with total hardness shows temporary hardness [65] indicated that with the high concentration of $\mathrm{Mg}^{2+}$ ions the degree of water hardness increases. A high positive loading of $\mathrm{Ca}^{2+}$ and $\mathrm{HCO}_{3}{ }^{-}$is attributed to various natural processes such as- weathering of rock minerals (limestone and calcium carbonate bearing rocks) and to various ion-exchange processes taking place in the groundwater system [63]. PC2 exhibits $18.39 \%$ of the total variance and the values of $\mathrm{Mg}^{2+}$ show high loading and the concentration of $\mathrm{HCO}_{3}{ }^{-}$ has moderate positive loading on the PC2 (Table 7). PC3 shows the $15.73 \%$ of the total variance with moderate positive loading on $\mathrm{Na}^{+}$, moderate negative score on $\mathrm{NO}_{3}{ }^{-}$. The significant inverse relationship between $\mathrm{Na}^{+}$and $\mathrm{NO}_{3}{ }^{-}$indicates the diverse source of chemical origin [66]. PC4 explains $9.1 \%$ of the total variance observed and has strong positive correlation value with $\mathrm{Na}^{+}$and moderately strong negative correlation with $\mathrm{Ca}^{2+}$. 
Table 7

Varimax rotated matrix of analyzed water samples

\begin{tabular}{|c|c|c|c|c|c|c|c|c|c|c|}
\hline \multirow[t]{2}{*}{ Variables } & \multicolumn{6}{|c|}{ Component (pre-monsoon) } & \multicolumn{4}{|c|}{ Component (post-monsoon) } \\
\hline & PC1 & PC2 & PC3 & PC4 & Communality & PC1 & PC2 & PC3 & PC4 & Communality \\
\hline $\mathrm{pH}$ & -0.302 & 0.735 & 0.147 & -0.044 & 0.656 & -0.078 & 0.275 & 0.811 & -0.127 & 0.756 \\
\hline EC & 0.236 & -0.899 & 0.072 & -0.192 & 0.907 & 0.757 & -0.587 & 0.004 & 0.089 & 0.925 \\
\hline TDS & 0.236 & -0.899 & 0.072 & -0.192 & 0.907 & 0.757 & -0.587 & 0.004 & 0.089 & 0.925 \\
\hline TH & 0.881 & -0.084 & -0.327 & 0.212 & 0.931 & 0.851 & 0.451 & 0.017 & 0.083 & 0.935 \\
\hline $\mathrm{Mg}^{2+}$ & 0.869 & -0.069 & -0.427 & 0.173 & 0.972 & 0.584 & 0.703 & -0.012 & 0.334 & 0.947 \\
\hline $\mathrm{Ca}^{2+}$ & -0.161 & -0.051 & 0.559 & 0.126 & 0.357 & 0.604 & -0.431 & 0.054 & -0.468 & 0.773 \\
\hline $\mathrm{K}^{+}$ & 0.018 & -0.257 & 0.767 & 0.079 & 0.661 & 0.607 & 0.312 & -0.462 & -0.067 & 0.682 \\
\hline $\mathrm{Na}^{+}$ & 0.689 & 0.565 & 0.438 & -0.138 & 0.934 & 0.207 & -0.114 & 0.632 & 0.654 & 0.883 \\
\hline $\mathrm{Cl}^{-}$ & 0.669 & 0.525 & 0.438 & -0.138 & 0.934 & 0.583 & -0.232 & 0.345 & -0.006 & 0.513 \\
\hline $\mathrm{HCO}_{3}{ }^{-}$ & 0.872 & 0.253 & -0.064 & 0.143 & 0.845 & 0.594 & 0.554 & -0.183 & -0.169 & 0.721 \\
\hline $\mathrm{SO}_{4}^{-}$ & -0.368 & 0.425 & -0.596 & -0.272 & 0.744 & 0.564 & 0.178 & 0.446 & -0.407 & 0.712 \\
\hline $\mathrm{NO}_{3}^{-}$ & -0.312 & -0.037 & 0.017 & 0.892 & 0.894 & 0.346 & -0.237 & -0.512 & 0.315 & 0.537 \\
\hline $\begin{array}{l}\text { Eigen } \\
\text { value }\end{array}$ & 3.642 & 3.036 & 1.966 & 1.098 & & 4.119 & 2.207 & 1.888 & 1.095 & \\
\hline $\begin{array}{l}\text { Cumulative } \\
\% \text { of } \\
\text { variance }\end{array}$ & 30.351 & 55.651 & 72.03 & 81.181 & & 34.32 & 52.71 & 68.44 & 77.56 & \\
\hline $\begin{array}{l}\% \text { of } \\
\text { variance }\end{array}$ & 30.351 & 25.301 & 16.379 & 9.151 & & 34.32 & 18.391 & 15.732 & 9.123 & \\
\hline
\end{tabular}

\section{Conclusion}

Usefulness of multivariate statistical methods along with WQI and graphical representation techniques is well illustrated in the present study. In the present study such tools are employed for understanding the physio-chemical characterization of river water system of Parbati river basin. The physicochemical parameter of all the analyzed water samples are well within the desirable limits prescribed by BIS and WHO. Therefore, the water quality is suitable for domestic purposes, except for the few locations where $\mathrm{pH}$ was beyond the permissible range in pre-monsoon season. Piper and Durov plot classified $100 \%$ of samples were of $\mathrm{Ca}^{2+}-\mathrm{Mg}^{2+}-\mathrm{HCO}_{3}{ }^{-}$water types indicating temporary hardness in both the seasons. Dominance of alkaline earth metals over that of alkalis and of weak acidic anions over that of strong acidic anions is well represented in the Piper cross plots. Moreover, Piper cross plots also highlighted the natural geochemical processes such as- weathering and dissolution of minerals. The results of Gibbs diagram indicated that the chemical composition of surface water in the Parbati river basin is strongly influenced by rock dominance, weathering of silicates in pre monsoon whereas dominance of rock is followed by precipitation in postmonsoon season. The WQI shows maximum water samples were falling in good class followed by excellent in both the seasons. PCA identifies the major factors influencing the surface water chemistry such as- rock-water interaction, ion exchange and leaching of parent materials as well as dominant anthropogenic factors like agri-runoff and domestic waste water runoff. 


\section{Competing interest}

All the authors declare that there is no competing economic interests or personal connections that could have appeared to impact the work reported in this manuscript.

\section{Acknowledgments}

Authors are grateful to the Director, G.B. Pant National Institute of Himalayan Environment (NIHE), Kosi-Katarmal, Almora, Uttarakhand for providing necessary facilities in Himachal Regional Centre of the Institute which could make the current study possible.

\section{Funding}

This research was funded by Mountain Division, $5^{\text {th }}$ Division of G B Pant National Institute of Himalayan Environment, KosiKatarmal, Almora, Uttarakhand, India.

\section{Data availability}

The datasets generated during and/or analyzed during the current study is available from the corresponding author on reasonable request.

\section{References}

1. Grimm NB, Faeth SH, Golubiewski NE, Redman CL, Wu J, Bai X, Briggs JM. Global change and the ecology of cities. science. 2008; 8; 319(5864):756-60.

2. Shiklomanov IA. Appraisal and assessment of world water resources. Water international. 2000; 25(1):11-32.

3. Singh S, Tanvir Hassan SM, Hassan M, Bharti N. Urbanisation and water insecurity in the Hindu Kush Himalaya: insights from Bangladesh, India, Nepal and Pakistan. Water Policy. 2020; 22(S1):9-32.

4. Santucci L, Carol E, Tanjal C. Industrial waste as a source of surface and groundwater pollution for more than half a century in a sector of the Río de la Plata coastal plain (Argentina). Chemosphere. 2018; 206:727-35.

5. Matta G, Kumar A, Naik PK, Kumar A, Srivastava N. Assessment of heavy metals toxicity and ecological impact on surface water quality using HPI in Ganga river. INAE Letters. 2018; 3(3):123-9.

6. Kumar P, Mahajan AK, Kumar A. Groundwater geochemical facie: implications of rock-water interaction at the Chamba city (HP), northwest Himalaya, India. Environmental Science and Pollution Research. 2019; 16:1-5.

7. Porcella DB, Sorensen DL. Characteristics of nonpoint source urban runoff and its effects on stream ecosystems. Corvallis Environmental Research Laboratory, Office of Research and Development, US Environmental Protection Agency; 1980.

8. Dalai TK, Krishnaswami S, Sarin MM. Major ion chemistry in the headwaters of the Yamuna river system: Chemical weathering, its temperature dependence and $\mathrm{CO} 2$ consumption in the Himalaya. Geochimical et Cosmochimica Acta. 2002; 1 ; 66(19):3397-416.

9. Jiang L, Yao Z, Liu Z, Wang R, Wu S. Hydrochemistry and its controlling factors of rivers in the source region of the Yangtze River on the Tibetan Plateau. Journal of Geochemical Exploration. 2015; 1; 155:76-83.

10. Sarkar A, Paul B. The global menace of arsenic and its conventional remediation-A critical review. Chemosphere. 2016; 1 ; 158:37-49.

11. Shanmuganandan S. Water quality, water resources and health water quality in relation to human health: a study with reference to water-borne diseases and major environmental issues in India subcontinent. Working paper, Madurai Kamaraj University, India; 1999.

12. DeNormandie J, Sunita J. Combating diarrhoeal disease in India through safe drinking water. World Health Organisation (WHO). http://www. who. int/mediacentre/multimedia/2002/ind_sanitation/en/index. htmL. 2002.

13. Rani S, Sreekesh S. Evaluating the responses of streamflow under future climate change scenarios in a Western Indian Himalaya Watershed. Environmental Processes. 2019; 6(1):155-74. 
14. Thakur N, Rishi M, Sharma DA, Keesari T. Quality of water resources in Kullu Valley in Himachal Himalayas, India: perspective and prognosis. Applied water science. 2018; 8(1):1-3.

15. District Disaster Management Plan (DDMP). Kullu district, Himachal Pradesh, India. 2011

16. Thakur N, Rishi M, Keesari T, Sharma DA, Sinha UK. Assessment of recharge source to springs in upper Beas basin of Kullu region, Himachal Pradesh, India using isotopic signatures. Journal of Radioanalytical and Nuclear Chemistry. 2020; 323(3):1217-25.

17. Maurya $P$, Kumari R, Mukherjee $S$. Hydrochemistry in integration with stable isotopes $(\delta 180$ and $\delta D)$ to assess seawater intrusion in coastal aquifers of Kachchh district, Gujarat, India. Journal of Geochemical Exploration. 2019; 196:42-56.

18. Adimalla N, Li P, Qian H. Evaluation of groundwater contamination for fluoride and nitrate in semi-arid region of Nirmal Province, South India: a special emphasis on human health risk assessment (HHRA). Human and ecological risk assessment: an international journal; 2018.

19. Herojeet R, Rishi MS, Lata R, Dolma K. Quality characterization and pollution source identification of surface water using multivariate statistical techniques, Nalagarh Valley, Himachal Pradesh, India. Applied Water Science. 2017; 7(5):2137-56.

20. Khanday SA, Romshoo SA, Jehangir A, Sahay A, Chauhan P. Environmetric and GIS techniques for hydrochemical characterization of the Dal lake, Kashmir Himalaya, India. Stochastic Environmental Research and Risk Assessment. 2018; 32(11):3151-68.

21. Zhao Y, Xia XH, Yang ZF, Wang F. Assessment of water quality in Baiyangdian Lake using multivariate statistical techniques. Procedia Environmental Sciences. 2012; 13:1213-26.

22. Simeonov V, Stratis JA, Samara C, Zachariadis G, Voutsa D, Anthemidis A, Sofoniou M, Kouimtzis T. Assessment of the surface water quality in Northern Greece. Water research. 2003; 37(17):4119-24.

23. Herojeet R, Rishi MS, Lata R, Sharma R. Application of environmetrics statistical models and water quality index for groundwater quality characterization of alluvial aquifer of Nalagarh Valley, Himachal Pradesh, India. Sustainable Water Resources Management. 2016; 2(1):39-53.

24. Central Ground Water Board (CGWB). Groundwater Information Booklet Kullu district Himachal Pradesh. Ministry of Water Resources, Government of India. 2013.

25. Choubey VM, Mukherjee PK, Bajwa BS, Walia V. Geological and tectonic influence on water-soil-radon relationship in Mandi-Manali area, Himachal Himalaya. Environmental geology. 2007; 52(6): 1163-1171.

26. Geological Survey of India. Geotherma; atlas of India (SpecialPublication no.19). 1991

27. Srikantia SV, Bhargava ON. Geology of Himachal Pradesh. GSI Publications. 1998; 2(1).

28. Biswas SS. Analysis of GIS based morphometric parameters and hydrological changes in Parbati River Basin, Himachal Pradesh, India. J Geogr Nat Disasters. 2016; 6(175): 2167-0587.

29. Environment Impact Assessment report of Parbati Hydro Electric Project. NHPC limited, District-Kullu (Himachal Pradesh), India. 2005

30. American Public Health Association, American Water Works Association, Water Pollution Control Federation, Water Environment Federation. Standard methods for the examination of water and wastewater. American Public Health Association.; 1912.

31. Hounslow AW. Water quality data: analysis and interpretation. CRC press; 2018.

32. Khalid S. An assessment of groundwater quality for irrigation and drinking purposes around brick kilns in three districts of Balochistan province, Pakistan, through water quality index and multivariate statistical approaches. Journal of Geochemical Exploration. 2019; 197:14-26.

33. Horton RK. An index number system for rating water quality. J Water Pollut Control Fed. 1965; 37(3):300-6.

34. Piper AM. A graphic procedure in the geochemical interpretation of water-analyses. Eos, Transactions American Geophysical Union. 1944; (6):914-28.

35. Durov SA. Natural waters and graphic representation of their composition. In Dokl Akad Nauk SSSR. 1948; 59(3): 87-90.

36. Gibbs RJ. Mechanisms controlling world water chemistry. Science. 1970; 170(3962):1088-90. 
37. Noori R, Sabahi MS, Karbassi AR, Baghvand A, Zadeh HT. Multivariate statistical analysis of surface water quality based on correlations and variations in the data set. Desalination. 2010; 260(1-3):129-36.

38. Hamid A, Bhat SA, Bhat SU, Jehangir A. Environmetric techniques in water quality assessment and monitoring: a case study. Environmental Earth Sciences. 2016; 75(4):321.

39. Jung KY, Lee KL, Im TH, Lee IJ, Kim S, Han KY, Ahn JM. Evaluation of water quality for the Nakdong River watershed using multivariate analysis. Environmental Technology \& Innovation. 2016; 5:67-82.

40. Kim JH, Kim RH, Lee J, Cheong TJ, Yum BW, Chang HW. Multivariate statistical analysis to identify the major factors governing groundwater quality in the coastal area of Kimje, South Korea. Hydrological Processes: An International Journal. 2005; 19(6):1261-76.

41. Barzegar R, Moghaddam AA, Tziritis E, Adamowski J, Nassar JB, Noori M, Kazemian N. Exploring the hydrogeochemical evolution of cold and thermal waters in the Sarein-Nir area, Iran using stable isotopes ( $\delta 180$ and $\delta D)$, geothermometry and multivariate statistical approaches. Geothermics. 2020; 85: 101815.

42. Singh KP, Malik A, Sinha S, Singh VK, Murthy RC. Estimation of source of heavy metal contamination in sediments of Gomti River (India) using principal component analysis. Water, air, and soil pollution. 2005; 166(1):321-41.

43. Helena B, Pardo R, Vega M, Barrado E, Fernandez JM, Fernandez L. Temporal evolution of groundwater composition in an alluvial aquifer (Pisuerga River, Spain) by principal component analysis. Water research. 2000; 34(3):807-16.

44. Vieira JS, Pires JC, Martins FG, Vilar VJ, Boaventura RA, Botelho CM. Surface water quality assessment of Lis river using multivariate statistical methods. Water, Air, \& Soil Pollution. 2012; 223(9):5549-61.

45. Liu CW, Lin KH, Kuo YM. Application of factor analysis in the assessment of groundwater quality in a blackfoot disease area in Taiwan. Science of the Total Environment. 2003; 313(1-3):77-89.

46. Ouyang Y. Evaluation of river water quality monitoring stations by principal component analysis. Water research. $2005 \mathrm{Jul}$ 1;39(12):2621-35..

47. Edition, F. Guidelines for drinking-water quality. WHO chronicle. 2011. 38(4), 104-108.

48. BIS ISDWS. Bureau of Indian Standards, New Delhi. 2012; 2-3.

49. Sawyer CN, McCarty PL. Chemistry for sanitary engineers. 1967.

50. Davis SN. Dewiest. Hydrogeology. 1966.

51. Williams EL, Szramek KJ, Jin L, Ku TC, Walter LM. The carbonate system geochemistry of shallow groundwater-surface water systems in temperate glaciated watersheds (Michigan, USA): Significance of open-system dolomite weathering. Geological Society of America Bulletin. 2007; 119(5-6):515-28.

52. Awadh SM, Ahmed RM. Hydrochemistry and pollution probability of selected sites along the Euphrates River, Western Iraq. Arabian Journal of geosciences. 2013; 6(7):2501-18.

53. Gaglioti S, Infusino E, Caloiero T, Callegari G, Guagliardi I. Geochemical characterization of spring waters in the Crati river basin, Calabria (Southern Italy). Geofluids. 2019; 2019.

54. Back W. Hydrochemical facies and ground-water flow patterns in Northern Atlantic Coastal Plain. AAPG Bulletin. 1960; 44(7):1244-5.

55. Chadha DK. A proposed new diagram for geochemical classification of natural waters and interpretation of chemical data. Hydrogeology journal. 1999; 7(5):431-9.

56. Ravikumar P, Somashekar RK, Prakash KL. A comparative study on usage of Durov and Piper diagrams to interpret hydrochemical processes in groundwater from SRLIS river basin, Karnataka, India. Elixir Earth Sci. 2015; 80(2015):31073-7.

57. Lloyd JW, Heathcote JA. Natural inorganic hydrochemistry in relation to ground water. 1985.

58. Bhat SA, Meraj G, Yaseen S, Pandit AK. Statistical assessment of water quality parameters for pollution source identification in Sukhnag stream: an inflow stream of lake Wular (Ramsar Site), Kashmir Himalaya. Journal of Ecosystems. 2014.

59. Gaury PK, Meena NK, Mahajan AK. Hydrochemistry and water quality of Rewalsar Lake of Lesser Himalaya, Himachal Pradesh, India. Environmental monitoring and assessment. 2018 Feb;190(2):1-22.

60. Brown RM, McClelland NI, Deininger RA, Tozer RG. A WATER QUALITY INDEX- DO WE DARE. 1970.

Page 15/19 
61. Husain MS, Umar R, Ahmad S. A comparative study of springs and groundwater chemistry of Beas and Parbati valley, Kullu District, Himachal Pradesh, India. HydroResearch. 2020; 3:32-47.

62. Shrestha S, Kazama F. Assessment of surface water quality using multivariate statistical techniques: A case study of the Fuji river basin, Japan. Environmental Modelling \& Software. 2007; 22(4):464-75.

63. Okiongbo KS, Douglas RK. Evaluation of major factors influencing the geochemistry of groundwater using graphical and multivariate statistical methods in Yenagoa city, Southern Nigeria. Applied Water Science. 2015; 5(1):27-37.

64. Srivastava SK, Ramanathan AL. Geochemical assessment of groundwater quality in vicinity of Bhalswa landfill, Delhi, India, using graphical and multivariate statistical methods. Environmental Geology. 2008; 53(7):1509-28.

65. Boyd CE, Tucker CS. Water quality and pond soil analyses for aquaculture. Water quality and pond soil analyses for aquaculture. 1992.

66. Hickman RE, Gray BJ. Trends in the quality of water in New Jersey streams, water years 1998-2007. U. S. Geological Survey; 2010.

\section{Figures}

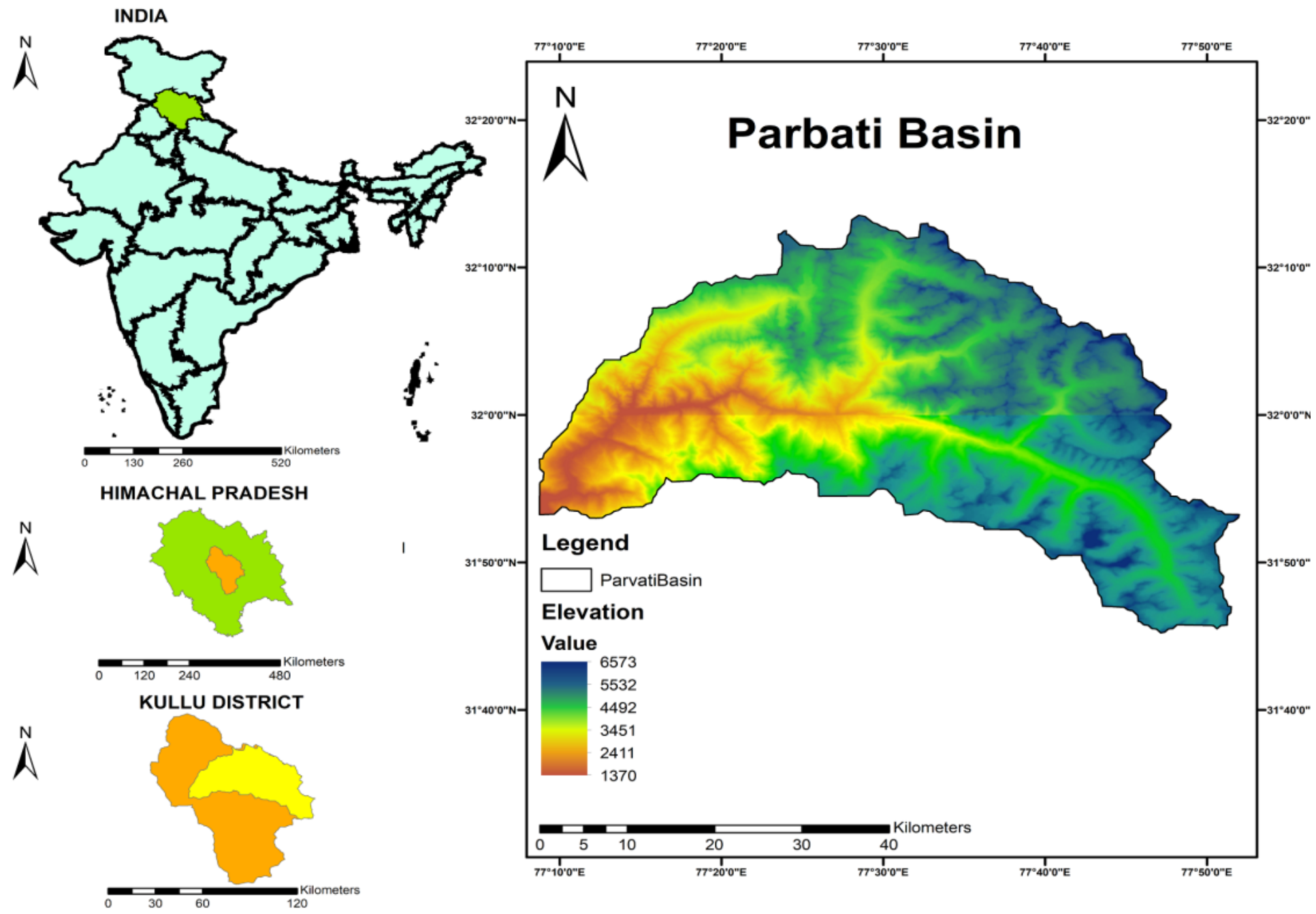

Figure 1

Location of the study area with altitude gradient Note: The designations employed and the presentation of the material on this map do not imply the expression of any opinion whatsoever on the part of Research Square concerning the legal status of any country, territory, city or area or of its authorities, or concerning the delimitation of its frontiers or boundaries. This map has been provided by the authors. 


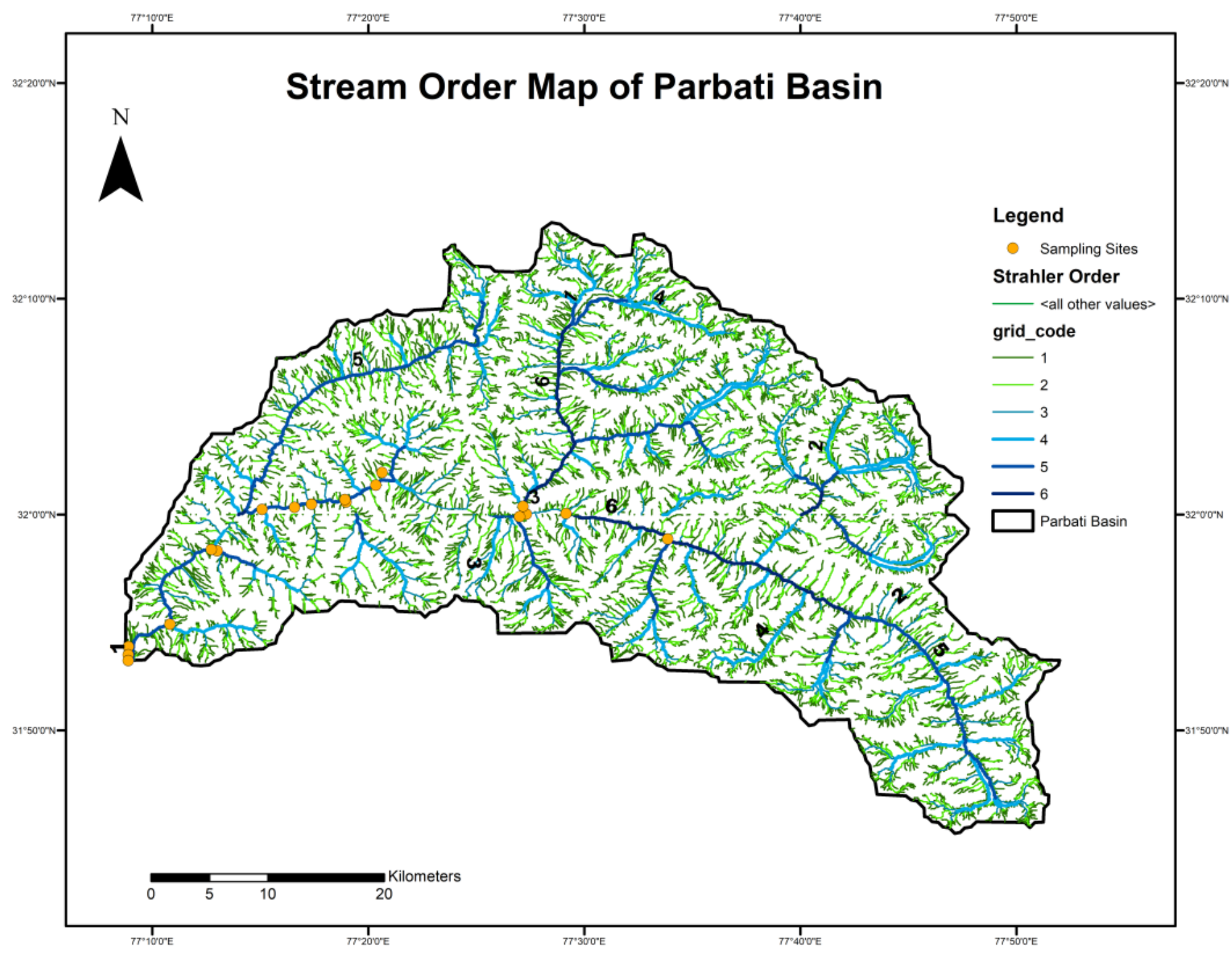

Figure 2

Drainage pattern and sampling sites of the study area Note: The designations employed and the presentation of the material on this map do not imply the expression of any opinion whatsoever on the part of Research Square concerning the legal status of any country, territory, city or area or of its authorities, or concerning the delimitation of its frontiers or boundaries. This map has been provided by the authors. 


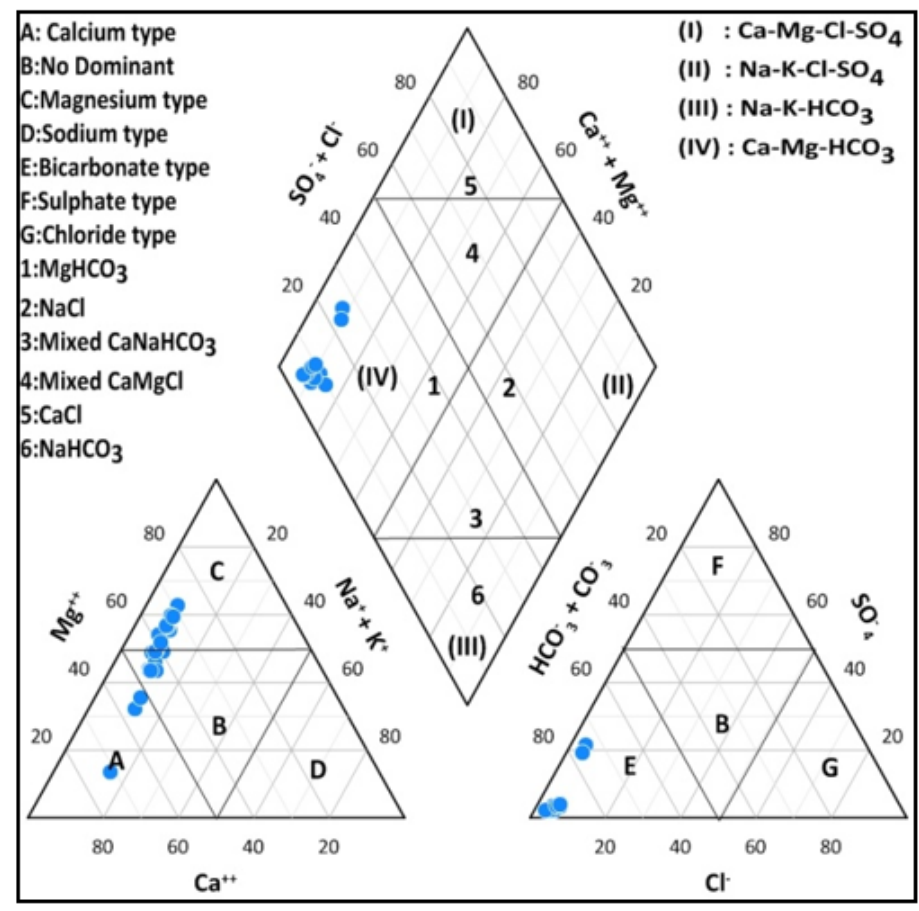

(a) Pre monsoon

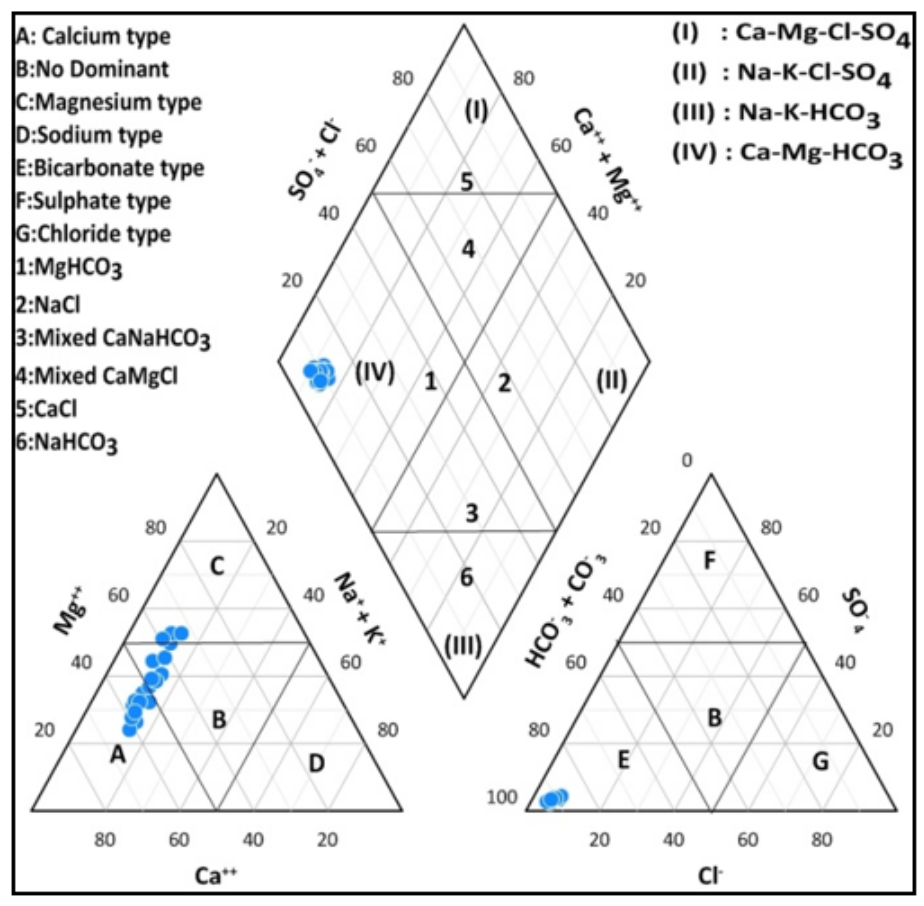

(b) Post monsoon

Figure 3

Piper classification diagram illustrating the chemical composition of surface water

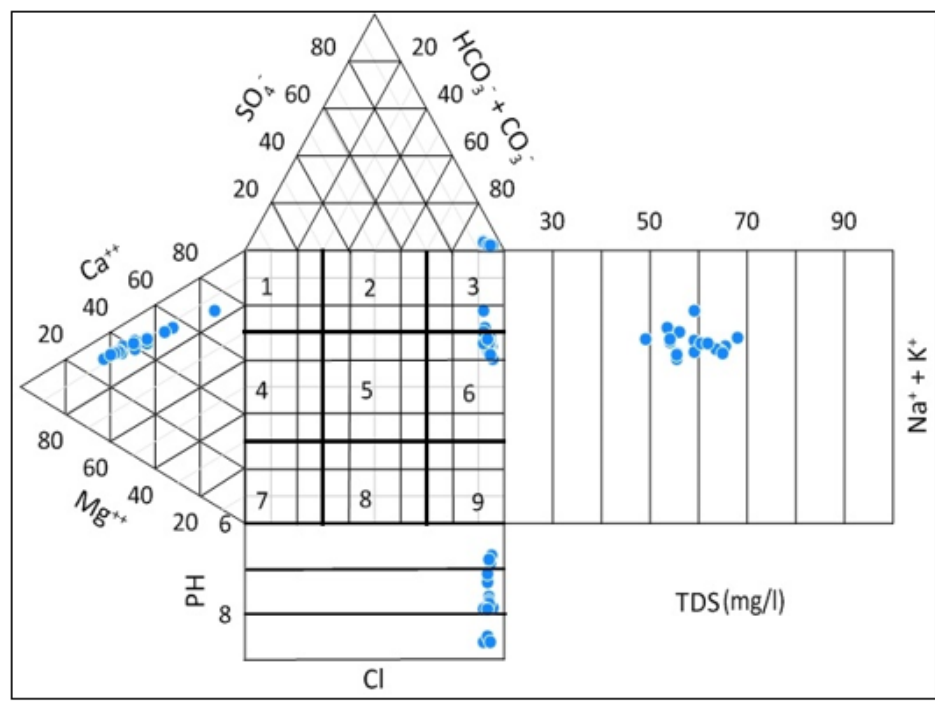

(a) Pre monsoon

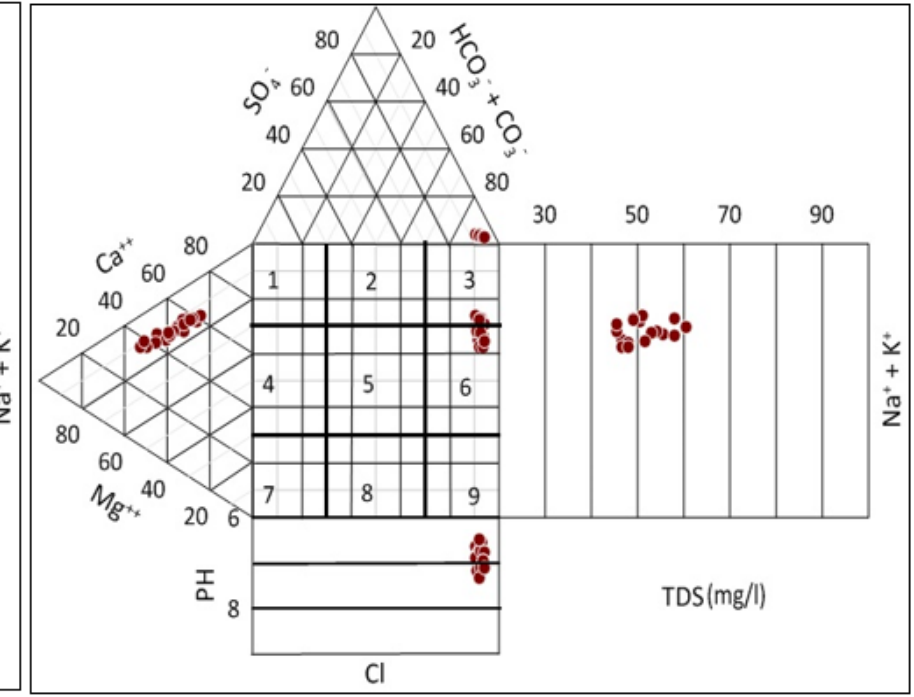

(b) Post monsoon

\section{Figure 4}

Durov diagram showing the hydro -chemical facies in the study area 

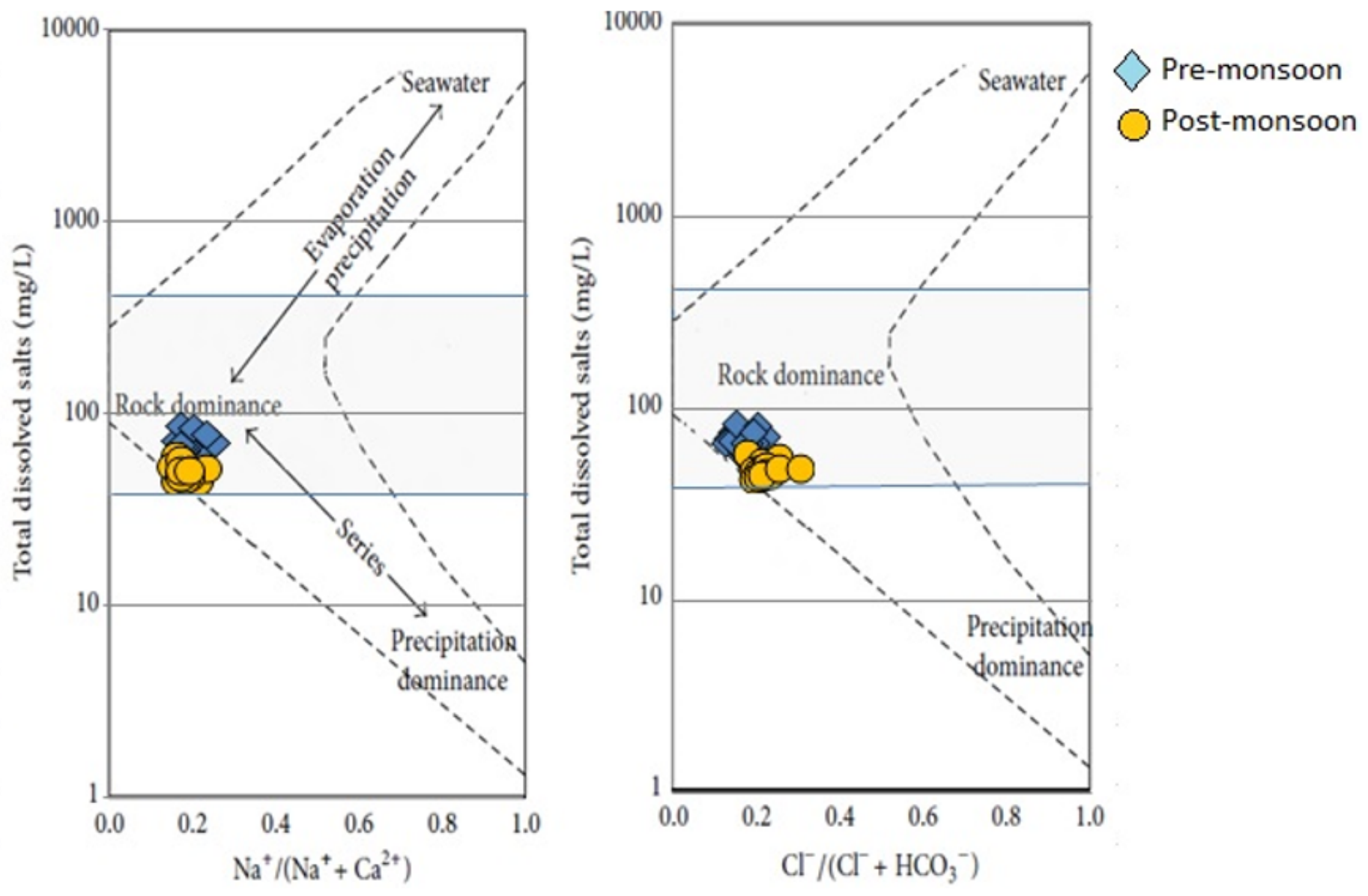

Figure 5

Mechanism controlling water chemistry in study area (after Gibbs 1970)

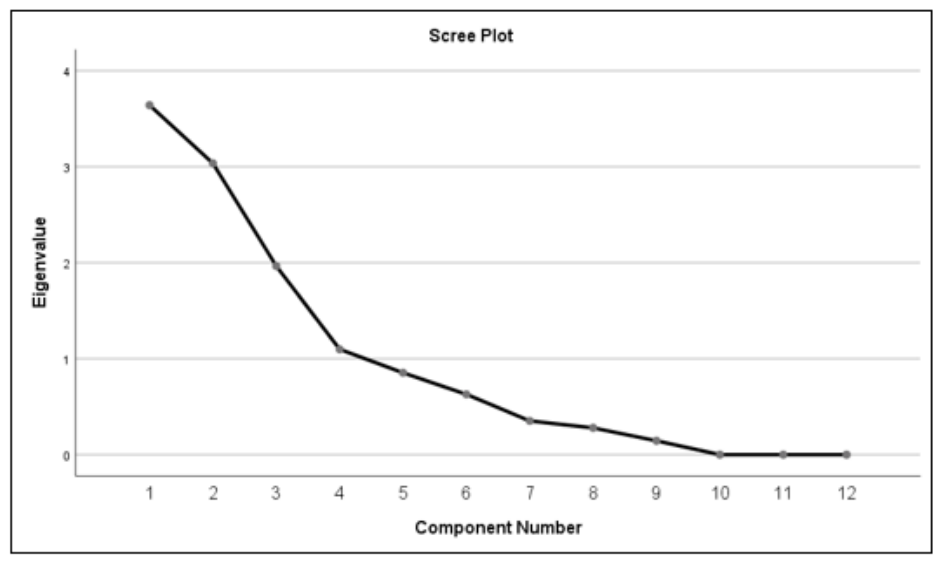

(a) Pre monsoon

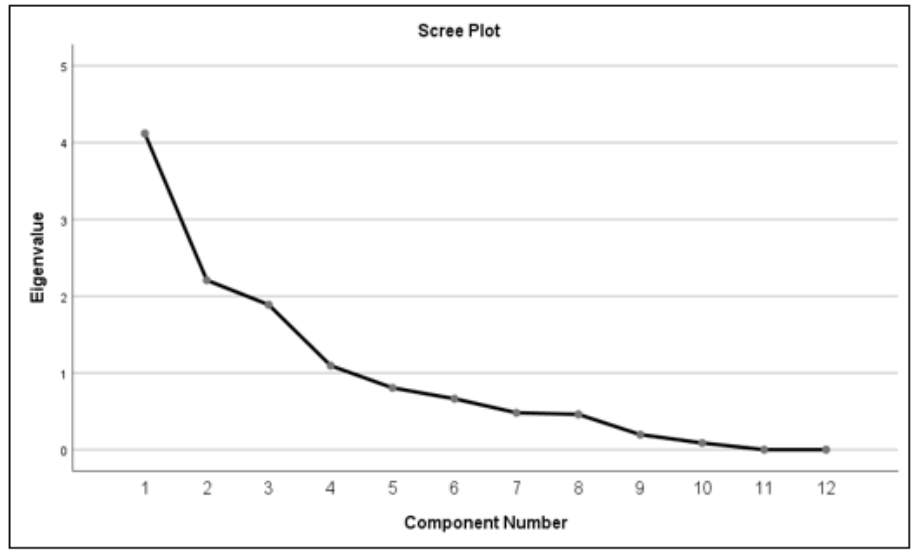

(b) Post monsoon

\section{Figure 6}

Scree plot extraction principal component in Pre monsoon and Post monsoon. 